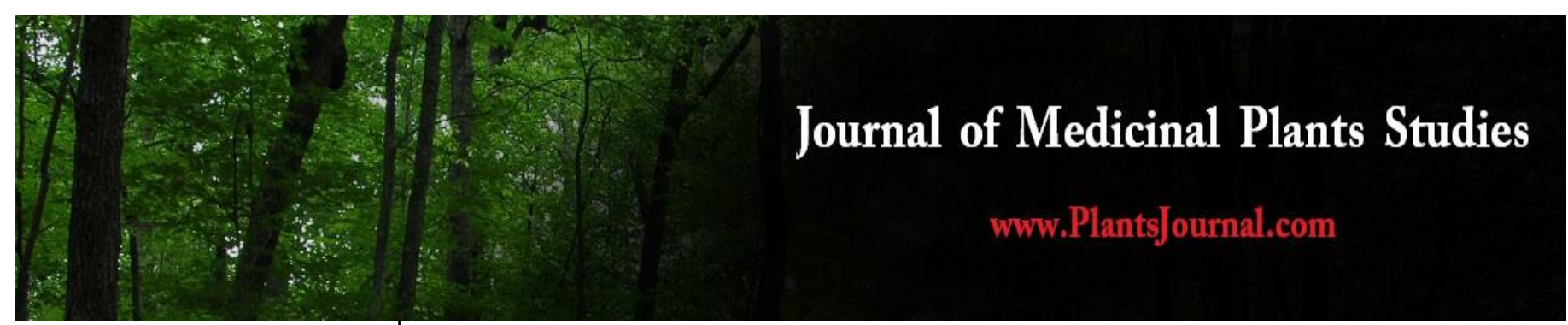

ISSN (E): 2320-3862

ISSN (P): 2394-0530

NAAS Rating: 3.53

www.plantsjournal.com

JMPS 2020; 8(5): 20-24

(C) 2020 JMPS

Received: 10-07-2020

Accepted: 16-08-2020

Adam Adenike A

Biomedicinal Research Centre,

Forestry Research Institute of

Nigeria, P.M.B. 5054, Ibadan,

Nigeria

Omogbene Temitope 0

Biomedicinal Research Centre,

Forestry Research Institute of

Nigeria, P.M.B. 5054, Ibadan,

Nigeria
Corresponding Author:

Adam Adenike A

Biomedicinal Research Centre,

Forestry Research Institute of

Nigeria, P.M.B. 5054, Ibadan,

Nigeria

\section{Phytochemical and Phytomineral (macro and trace) compositions of the leaf, stem bark and root of Blighia sapida K.D. Koenig}

\author{
Adam Adenike A and Omogbene Temitope $O$
}

DOI: https://doi.org/10.22271/plants.2020.v8.i5a.1190

\begin{abstract}
Foreign invasions and essential elements inadequacy in the body result in abnormal biological functions of the body, however, medicinal plants trigger desired therapeutic effects through their available phytochemicals and mineral supplementations. Blighia sapida is employed traditionally for the treatment of conjuctivitis, diarrhoea, epilepsy, malaria, internal haemorrhage, ulcer, migraine and as a laxative, among others. This study was designed to analyze the phytochemicals and essential elements present in B.sapida leaf, stem bark and root. The result obtained showed the presence of flavonoids, alkaloids, cardiac glycosides and saponins in all the plant parts but anthraquinones. The highest concentrations of $\mathrm{Ca}, \mathrm{Mg}$ and $\mathrm{K}$ were recorded in the stem bark $(6.57 \pm 0.16 \mathrm{mg} / \mathrm{g})$, and leaf $(1.07 \pm 0.03 \mathrm{mg} / \mathrm{g}$ and $0.44 \pm 0.01$ $\mathrm{mg} / \mathrm{g}$ ) respectively while the leaf had the highest concentration of $\mathrm{Mn}, \mathrm{Fe}, \mathrm{P}$ and $\mathrm{Cu}(0.0116 \pm 0.00 \mathrm{mg} / \mathrm{g}$, $0.4747 \pm 0.03 \mathrm{mg} / \mathrm{g}, 0.1142 \pm 0.00 \mathrm{mg} / \mathrm{g}$ and $0.0011 \pm 0.00 \mathrm{mg} / \mathrm{g}$ ) respectively. This study justifies the ethnopharmacological uses of $B$. sapida, thus, further studies on the mechanism of action are paramount in order to elucidate the therapeutic roles of all the phytoconstituents.
\end{abstract}

Keywords: Bioactive ingredients, ethnopharmacological uses, medicinal plants, mineral elements, secondary metabolites, therapeutic effects

\section{Introduction}

The lack or inadequacy of an essential element in the human body results in abnormal biological functions or development of the body, and is often managed by dietary supplementation of the particular element. The insufficiency of red blood cells in the body characterized by anaemia, for example, has been associated with iron deficiency ${ }^{[1]}$ as iron serves as a transporter of oxygen in the body and its plant sources are found (in considerable amount) in legumes such as Lathyrus roduntifolius roots, Vicia faba (bean flour), and soybeans cooked seed, as well as vegetables such as Curcubita pepo (green creole pumpkin), Cichorium endivia (endive leaves), and Allium porum (leeks) ${ }^{[2]}$. Goitre, on the other hand, is a swelling of the thyroid gland that causes a lump - which moves up and down when food is swallowed - in the front of the neck ${ }^{[3]}$. It was not until the 19th century, however, that trace amounts of iodine were found to eliminate goitre ${ }^{[1]}$. Although these elements are essential components of biological activities, their excessive levels can be toxic to the body health and may lead to many fatal diseases, such as cancers ${ }^{[4]}$. Essential elements are categorized into macro and trace elements. The macro-minerals are present in the body in somewhat small amounts, so correspondingly lower levels are required in the diet, while the other essential elements (trace elements) are present in smaller amounts, ranging from a few grams to a few milligrams in an adult human ${ }^{[1]}$. They play important roles in man's health vitality likewise phytochemicals. Moreover, desired therapeutic effect is triggered by medicinal plants in an ailing body as a result of certain biologically active ingredients (phytochemicals) in them which are the substances engaged in drug discovery and development. Gracelin et al. ${ }^{[5]}$ noted that plants are endowed with various phytochemical molecules such as vitamins, terpenoids, phenols, lignins, tannins, flavonoids, alkaloids, amines and other metabolites which are rich source of free radical scavengers.

Before the advent of allopathic drugs, medicinal plants have been a reliable source that salvaged man's health from various diseases, both mild and life-threatening. These remedies cover different phyto-pharmaceutical plant-types among which medicinal trees are enumerated. 
The parts of such trees, especially, the leaves, stem bark and roots are often engaged in the treatment of several diseases traditionally. Hassan et al. ${ }^{[6]}$ pointed out that the use of medicinal plants in Nigeria cut across social and economic classes, as over $80 \%$ of Nigerians depend on medicinal plants in treating various acute and chronic diseases.

Blighia sapida, commonly known as akee apple or savory akee, and planted as ornamental shade tree, belongs to Sapindaceae family. It is called different names among the major ethnic tribes in Nigeria; 'Gwanja Kusa' (Hausa), 'Isin' (Yoruba) and 'Okpu' (Igbo). It has compound leaves with 3-5 pairs of oblong, ovate - oblong, or elliptical leaflets 1.5-3.0 $\mathrm{cm}$ long. The fleshy aril of the fruit can be eaten but the seed is inedible. The evergreen tree, of about 33 to $40 \mathrm{ft}$ with a dense crown of spreading branches, occurs naturally from Senegal to Cameroon and Equatorial Guinea, and possibly also in Gabon ${ }^{[7-8]}$. The wood is mainly used for light construction and furniture, and sometimes in woodcraft. $B$. sapida is widely engaged in traditional medicine to treat numerous diseases such as ophthalmia and conjunctivitis, intercostal pain, dysentery and diarrhoea, epilepsy, oedema, dental decay, fever, malaria, internal haemorrhage, burns, eyes inflammation, yellow fever, constipation, cutaneous infections, whitlow, head lice, diuretic migraine and as a laxative, among others ${ }^{[8,9]}$. In Côte d'Ivoire and Nigeria, ground leaves are applied as a paste together with plant salts to treat yaws and ulcers ${ }^{[8]}$.

The aim of this study, therefore, was to evaluate and compare the bioactive compounds and essential mineral elements present in the leaf, stem bark and root of B. sapida in order to determine the usefulness of the plant parts in the management of diseases and infections.

\section{Materials and Methods \\ Plant Materials}

Blighia sapida leaves, stem bark and root samples were harvested fresh from the Herbal Gene Bank of the Biomedicinal Research Centre (BMRC) and identified at the Forestry Herbarium Ibadan (FHI) in the Forestry Research Institute of Nigeria, Ibadan.

\section{Sample Preparation}

The leaves and stem bark samples were rinsed with clean water to remove dust and dirt while the root samples were thoroughly washed using clean water repeatedly until the soil was completely removed. The plant samples were then airdried, milled into fine powder and stored in air-tight jars for experimental analysis.

\section{Qualitative Determination of Phytochemicals}

Phytochemical analysis of powdered B. sapida leaf, stem bark and root was carried out at the Biomedicinal Research Centre Laboratory, Forestry Research Institute of Nigeria (FRIN) and was done according to standard methods with some modifications.

\section{Determination of Tannins (Ferric chloride test)}

About $0.5 \mathrm{~g}$ of powdered sample was stirred with about $10 \mathrm{ml}$ of distilled water and then filtered. To $2 \mathrm{ml}$ of the filtrate, few drops of $1 \%$ ferric chloride solution were added. An occurrence of green or blue-green precipitate indicated the presence of tannins ${ }^{[10]}$.

\section{Determination of Anthraquinones (Borntrager's test)}

About $0.5 \mathrm{~g}$ of powdered sample was shaken with $10 \mathrm{ml}$ of
$10 \% \mathrm{HCl}$ for 5 minutes and filtered while hot. Vigorous shaking was avoided while the cooled filtrate was partitioned against equal volumes of chloroform. Chloroform layer was then carefully transferred to a clean tube and equal volume of $10 \%$ ammonia was added. The presence of combined anthraquinones was indicated by a pink, red or violet colour in the aqueous layer ${ }^{[12]}$.

\section{Determination of Flavonoids (Sodium hydroxide test)}

About $0.5 \mathrm{~g}$ of powdered sample was dissolved in $5 \mathrm{ml}$ of water and filtered; to this $2 \mathrm{ml}$ of the $10 \%$ aqueous sodium hydroxide was later added to produce a yellow colouration. A change in colour from yellow to colourless on addition of dilute hydrochloric acid was an indication of the presence of flavonoids ${ }^{[10]}$.

\section{Determination of Cardiac Glycosides (Keller-killani test)}

About $0.5 \mathrm{~g}$ of powdered sample was extracted with $5 \mathrm{ml}$ of $80 \%$ ethanol for 5 minutes on a water bath and filtered. Cooled filtrate was diluted with equal volumes of distilled water. A few drops of lead acetate solution was added, shaken and filtered after standing for few minutes. The filtrate was then extracted with aliquots of chloroform and evaporated to dryness on steam bath. Dried extract was dissolved in $2 \mathrm{ml}$ of glacial acetic acid containing one drop of $1 \% \mathrm{FeCl}_{3}$ solution in a clean test tube. $2 \mathrm{ml}$ of conc. $\mathrm{H}_{2} \mathrm{SO}_{4}$ was then poured down the side of the tube so as to form a layer below the acetic acid. The formation of a purple, reddish-brown or brown ring at the interface or a green colour in the acetic layer indicated the presence of cardiac glycosides ${ }^{[11]}$.

\section{Determination of Saponins (Frothing test)}

About $0.5 \mathrm{~g}$ of powdered sample was boiled with $5 \mathrm{ml}$ of distilled water and filtered. To the filtrate, about $3 \mathrm{ml}$ of distilled water was further added and shaken vigorously for about 5 minutes. Frothing, which persisted after the solution simmered down, was taken as an evidence for the presence of saponins ${ }^{[11]}$.

\section{Determination of Alkaloids}

About $0.5 \mathrm{~g}$ of powdered sample was stirred in $5 \mathrm{ml}$ of $10 \%$ $(\mathrm{v} / \mathrm{v}) \mathrm{HCl}$ on a steam bath and filtered. Few drops each of Meyer's, Wagner's and Dragendorff's reagents were added to $1 \mathrm{ml}$ of cooled filtrate in separate test tubes. The presence of alkaloids was indicated by the formation of precipitate or turbidity ${ }^{[11]}$.

\section{Determination of Phenols (Ferric chloride test)}

About $0.5 \mathrm{~g}$ of powdered sample was dissolved in $5 \mathrm{ml}$ of distilled water. To this, few drops of $5 \%$ ferric chloride solution were added. A dark green colour indicated the presence of phenolic compounds ${ }^{[10]}$.

\section{Determination of Terpenoids (Salkowski test)}

About $0.5 \mathrm{~g}$ of the powdered sample was dissolved in $3 \mathrm{ml}$ of chloroform. $1 \mathrm{ml}$ of conc. $\mathrm{H}_{2} \mathrm{SO}_{4}$ was carefully added to the filtrate to form a layer. A reddish-brown colour at the interface was taken as a positive result for terpenoids ${ }^{[11]}$.

\section{Determination of Steroids (Liebermann-Burchard test)}

To $0.2 \mathrm{~g}$ of the powdered sample, $2 \mathrm{ml}$ of acetic acid was added, the solution was cooled well in ice and conc. $\mathrm{H}_{2} \mathrm{SO}_{4}$ was carefully added. The presence of a steroidal ring (aglycone portion of cardiac glycoside) was indicated by a colour development from violet to blue or bluish-green ${ }^{[11]}$. 


\section{Elemental analysis}

Elemental analysis of B. sapida leaf, stem bark and root was carried out at the Soils and Tree Nutrition laboratory, FRIN, using Bulk Atomic Absorption Spectrophotometer (AAS), according to standard method of AOAC ${ }^{[13]}$.

\section{Statistical analysis}

Data obtained were subjected to One-Way Analysis of Variance followed by Fisher's Least Significant Difference (LSD) test where p-values $>0.05$ were taken to be statistically significant.

\section{Result}

The result of the phytochemical test of Blighia sapida as shown in Table 1 revealed that the leaves, stem bark and root all contain flavonoids, alkaloids, cardiac glycosides and saponins. Phenols, terpenoids and steroids were only found in the stem bark and root but absent in the leaf. Anthraquinones were not detected in any of the plant parts. The phytochemical observation in this study differs from Ologundudu et al. ${ }^{[14]}$ which reported the absence of flavonoids, tannins and alkaloids in the aqueous extract of B. sapida leaf and stem bark. According to Ekué et al. ${ }^{[9]}$, steroids were not detected in the stem bark aqueous extract of B. sapida as different from this study. Tannins, which were absent in the root as observed in this study, were reportedly present in the root bark of $B$. sapida as observed by Saidul et al. ${ }^{[15]}$. Nevertheless, this study confirms other phytochemical constituents in previous reports ${ }^{[14,16]}$.

Result of the elemental analysis as presented in Table 2 revealed that the leaves, stem bark and root of $B$. sapida contain considerable amounts of mineral elements. $\mathrm{Na}, \mathrm{Ca}$, $\mathrm{Mg}$ and $\mathrm{K}$ are macro elements observed in the plants parts.
These minerals are essential for the body and so make this result important. However, there is a significant difference in the concentrations of $\mathrm{Ca}, \mathrm{Mg}$ and $\mathrm{K}$ among all the plant parts of $B$. sapida studied as the highest concentration of $\mathrm{Ca}$ is recorded in the stem bark with $6.57 \pm 0.16 \mathrm{mg} / \mathrm{g}$; $\mathrm{Mg}$ and $\mathrm{K}$, in the leaf with $1.07 \pm 0.03 \mathrm{mg} / \mathrm{g}$ and $0.44 \pm 0.01 \mathrm{mg} / \mathrm{g}$ respectively. There is no significant difference between the stem bark and root of $\mathrm{Na}$ concentrations as the highest concentration is found in the leaf with $0.067 \pm 0.00 \mathrm{mg} / \mathrm{g}$. Trace elements found in this study are $\mathrm{Mn}, \mathrm{Cu}, \mathrm{Fe}, \mathrm{Zn}, \mathrm{P}, \mathrm{Cr}$. However, a significant difference was observed in the concentrations of $\mathrm{Mn}, \mathrm{Fe}$ and $\mathrm{P}$ among all the plant parts as the highest concentration of these elements is recorded in the leaf with $0.0116 \pm 0.00 \mathrm{mg} / \mathrm{g}, \quad 0.4747 \pm 0.03 \mathrm{mg} / \mathrm{g}$ and $0.1142 \pm 0.00 \mathrm{mg} / \mathrm{g}$ respectively. There is no significant difference among all the plant parts for $\mathrm{Zn}$ concentrations. The highest concentration of $\mathrm{Cu}$ is recorded in the leaf with $0.0011 \pm 0.00 \mathrm{mg} / \mathrm{g}$ as the significant difference is observed only between the stem bark and root.

Table 1: Phytochemical composition of leaf, stem bark and root of B. sapida

\begin{tabular}{|c|c|c|c|}
\hline Bioactive agent & Leaf & Stem bark & Root \\
\hline Tannins & + & + & - \\
\hline Anthraquinones & - & - & - \\
\hline Flavonoids & + & + & + \\
\hline Cardiac Glycosides & + & + & + \\
\hline Saponins & + & + & + \\
\hline Alkaloids & + & + & + \\
\hline Phenols & - & + & + \\
\hline Terpenoids & - & + & + \\
\hline Steroid & - & + & + \\
\hline
\end{tabular}

Activity Key: + = test positive - = test negative

Table 2: Elemental composition (mg/g) of leaf, stem bark and root of B. sapida

\begin{tabular}{|c|c|c|c|c|}
\hline $\mathbf{2 . 1}$ & \multicolumn{4}{|c|}{ Macro Elements } \\
\hline & Na & Ca & Mg & K \\
\hline Leaf & $0.067 \pm 0.00^{\mathrm{a}}$ & $2.65 \pm 0.06^{\mathrm{b}}$ & $1.07 \pm 0.03^{\mathrm{a}}$ & $0.44 \pm 0.01^{\mathrm{a}}$ \\
\hline Stem bark & $0.047 \pm 0.00^{\mathrm{b}}$ & $6.57 \pm 0.16^{\mathrm{a}}$ & $0.92 \pm 0.02^{\mathrm{b}}$ & $0.19 \pm 0.00^{\mathrm{b}}$ \\
\hline Root & $0.053 \pm 0.00^{\mathrm{b}}$ & $0.33 \pm 0.02^{\mathrm{c}}$ & $0.52 \pm 0.02^{\mathrm{c}}$ & $0.16 \pm 0.00^{\mathrm{c}}$ \\
\hline
\end{tabular}

\begin{tabular}{|c|c|c|c|c|c|c|}
\hline $\mathbf{2 . 2}$ & \multicolumn{5}{|c|}{ Trace Elements } \\
\hline & Mn & $\mathbf{C u}$ & $\mathbf{F e}$ & $\mathbf{Z n}$ & $\mathbf{P}$ & $\mathbf{C r}$ \\
\hline Leaf & $0.0116 \pm 0.00^{\mathrm{a}}$ & $0.0011 \pm 0.00^{\mathrm{a}}$ & $0.4747 \pm 0.03^{\mathrm{a}}$ & $0.0022 \pm 0.00^{\mathrm{a}}$ & $0.1142 \pm 0.00^{\mathrm{a}}$ & $0.0005 \pm 0.00^{\mathrm{a}}$ \\
\hline Stem bark & $0.0023 \pm 0.00^{\mathrm{b}}$ & $0.0003 \pm 0.00^{\mathrm{b}}$ & $0.1357 \pm 0.01^{\mathrm{c}}$ & $0.0023 \pm 0.00^{\mathrm{a}}$ & $0.0777 \pm 0.00^{\mathrm{b}}$ & $0.0003 \pm 0.00^{\mathrm{b}}$ \\
\hline Root & $0.0015 \pm 0.00^{\mathrm{c}}$ & $0.0005 \pm 0.00^{\mathrm{b}}$ & $0.3227 \pm 0.00^{\mathrm{b}}$ & $0.0023 \pm 0.00^{\mathrm{a}}$ & $0.0225 \pm 0.00^{\mathrm{c}}$ & $0.0004 \pm 0.00^{\mathrm{ab}}$ \\
\hline
\end{tabular}

\section{Discussion}

Phytochemicals play roles that are essential in many metabolic activities as they confer therapeutic potentials on medicinal plants. Flavonoids are free radical scavengers which prevent oxidative cell damage and have strong anticancer activity ${ }^{[16-17]}$. This is an indication that $B$. sapida may be engaged in the management of oxidative stress-related disorder. B. sapida may also be effective in the treatment of heart-related problems as the confirmed presence of cardiac glycosides are notable for the management of heart failure and maintenance of normal cardiac rhythm ${ }^{[18]}$. Tannins hasten the healing of wounds and inflamed mucous membrane ${ }^{[19]}$ as well as possess potential anti-viral, anti-bacterial and antiparasitic agents $[20,21]$. These properties tend to justify the ethnomedicinal uses of $B$. sapida in the treatment of snakebite, scorpion sting, head lice, ulcer, burns, cutaneous infection and viral infection such as whitlow [8, 9]. The neutralization of some harmful enzymes in the intestine and susceptibility of several infectious protozoans are characteristic of saponins which can also build the immune system and promote wound healing ${ }^{[22]}$. This may be the reason behind the traditional use of $B$. sapida as laxative and in the effective management of diarrhoea, dysentery, burns and ulcer ${ }^{[9]}$. The presence of alkaloid in the plant may also account for its ethnomedicinal uses in the treatment of intercostal pain, migraine and constipation [9] as alkaloids have been documented to possess analgesic, antispasmodic and bactericidal effects ${ }^{[19]}$. Phenols and phenolic compounds possess immense antimicrobial properties and have been extensively used in disinfections and remain the standards with which other bactericides are compared [23, 24]. The traditional uses of $B$. sapida against bacterial infections such as dental decay and abscess may be attributed to the presence of phenolic compounds in the plant. Inflammatory issues such as ophthalmia, yaws and oedema have been managed traditionally ${ }^{[8]}$. This may be as result of the presence of steroids which are effective as anti-inflammatory agents ${ }^{[25]}$, they also promote cell growth in particular muscle tissue and 
bone ${ }^{[26,27]}$. The presence of terpenoids in B. sapida supports its ethnomedicinal uses in the management of conjunctivitis and other eye-related problems ${ }^{[8]}$ as terpenoids play important roles for vision and are effective for their antioxidative capacity ${ }^{[28]}$.

The requirement of certain nutrients, known as macro elements by the body for sustainable biological functions has sparked interest in plant and food which harbour these elements. Sodium $(\mathrm{Na})$, along with potassium $(\mathrm{K})$, is an electrolytic compound necessary for humans to regulate the physical fluids system. It is also required for nerve and muscle functioning but over-consumption can lead to kidney damage and increased chances of high blood pressure ${ }^{[29]}$. Calcium $\left(\mathrm{Ca}^{+2}\right)$ and magnesium $\left(\mathrm{Mg}^{+2}\right)$ act as binding agents to fuse the cell walls together and are present in exchangeable amounts ${ }^{[30]}$.The excess fluid excretion as a result of $\mathrm{Na}-\mathrm{K}$ relationship in the body may account for the traditional use of $B$. sapida in the treatment of oedema, however, the lower $\mathrm{Na}$ and $\mathrm{K}$ content of $B$. sapida is advantageous because of its relationship with hypertension in humans. The cell wall fusion action of $\mathrm{Ca}$ and $\mathrm{Mg}$ present in B. sapida seem to justify the traditional uses of $B$. sapida in the treatment of burns and ulcer ${ }^{[8]}$. Moreover, some trace elements have structural roles and are responsible for the stability of important biological molecules yet their excessive levels can be toxic for the body health ${ }^{[4]}$. Manganese (Mn) helps the body to form connective tissue, bones, blood-clotting factors, and sex hormones ${ }^{[31,32]}$. Iron (Fe) can bind, transport, and release oxygen in the body ${ }^{[33]}$. The traditional use $B$. sapida in the management of haemorrhage ${ }^{[9]}$ may be due to its $\mathrm{Fe}$ content. Copper $(\mathrm{Cu})$ is necessary for survival as it is found in all body tissues maintaining nerve cells and the immune system. It also plays a role in the transfer of Fe from tissues to the plasma ${ }^{[34,35]}$. The presence of $\mathrm{Cu}$ may be the justification for the folkloric uses of B. sapida in the treatment of neurological disorder such as epilepsy ${ }^{[8,9]}$. Zinc $(\mathrm{Zn})$ is particularly important for healthy skin and is essential for a healthy immune system and resistance to infection ${ }^{[36]}$. The immune response and infection resistance action of $\mathrm{Zn}$ in $B$. sapida may be the reason behind its ethnomedicinal effectiveness against child fever, yellow fever and malaria ${ }^{[8]}$. Chromium has been found to serve important function in improved sugar metabolism through the activation of insulin and the stimulation of fatty acid and cholesterol synthesis from acetate in the liver ${ }^{[37,39]}$. Phosphorus (P), the second most abundant mineral in the body, makes up about $1 \%$ of a person's total body weight and is present in every cell of the body ${ }^{[39]}$, with the bones and teeth containing the largest proportion. Phosphorus helps the body make ATP, a molecule the body uses to store energy. It also aids kidney function, muscle contractions, normal heartbeat and nerve signalling [39]. The presence of phosphorous in B. sapida may be responsible for its folkloric functions in the management of internal haemorrhage and epilepsy ${ }^{[8,9]}$.

\section{Conclusion}

B. sapida K.D. Koenig is an essential medicinal plant useful for the treatment of various health conditions. This study revealed the richness of $B$. sapida in phytochemical ingredients and essential elements and justified the ethnopharmacological uses of the plant species. Hence, $B$. sapida can be considered for possible inclusion in herbal drug formulations targeted towards specific ailments such as conjunctivitis, diarrhoea, epilepsy, dental decay, fever, malaria, internal haemorrhage, diuretic migraine, etc. The findings of this study also show a considerable concentration of mineral elements which can be engaged in the management of mineral deficiencies in humans. However, further elucidative studies on the mechanism of action of B. sapida that will explain the therapeutic roles of its phytochemicals and mineral elements in the management of arrays of maladies are recommended.

\section{Acknowledgement}

The authors like to express sincere appreciation to the Head of Biomedicinal Research Centre, Dr. I.O. Lawal for his support during the course of this research.

\section{Conflict of Interest}

The authors declare no conflict of interest.

\section{References}

1. LibreTexts. Essential elements for life.Chemistry. 2019. Accessed from https://chem.libretexts.org/Bookshelves/General_Chemist ry/Book\%3A_Chemistry(Averill_and_Eldredge)/01\%3A _Introduction_to_Chemistry/1.8\%3A_Essential_Element s_for_Life on May 22, 2020.

2. Valdes-Miramontes E, Rodriguez-Macias R, Ruiz, M. Vegetal Sources of Iron. IntechOpen 2018. Doi: http://dx.doi.org/10.5772/intechopen.79834

3. NHS. 2019. Goitre. Accessed from https://www.nhs.uk/conditions/goitre/ on August 8, 2020.

4. Al-Fartusie FS, Mohssan SN. Essential trace elements and their vital roles in human body. Indian J. Advances in Chem Sci. 2017; 5(3):127-136. Doi: http://dx.doi.org/10.22607/IJACS.2017.503003.

5. Gracelin DH, Britto AJ, Kumar BJR. Qualitative and quantitative analysis of phytochemicals in five Pteris Species.Intl J. Pharm Pharmaceut Sci. 2012; 5:105-107.

6. Hassan HS, Sule MI, Musa AM, Musa KY, Abubakar MS, Hassan AS et al. Anti-inflammatory activity of crude saponin extracts from five Nigerian medicinal plants.Afr J Tradit Complement Altern Med. 2012; 9(2):250-5.

7. Aderinola OA, Farinu GO, Akinlade JA, Olayemi TB, Ojebiyi OO, Ogunniyi PO et al. Nutritional potential of Blighiasapida K Konig (Ackeeakkee) leaves as a dry season feed resources for West Africa dwarf goats in the derived savanna zone of Nigeria. Livestock Res. Rural Dev. 19(6):78.

8. Asamoah A, Antwi-Bosiako C, Frimpong-Mensah K, AttaBoateng A, Montes CS, Louppe D et al. Blighiasapida K.D. Koenig. In: Lemmens RHMJ, Louppe D, Oteng-Amoako AA. (Editors).Prota 7(2): Timbers/Bois d'œuvre 2. [CD-Rom]. PROTA, Wageningen, Netherlands.

9. Ekué MR, Sinsin B, Eyog-Matig O et al. Uses, traditional management, perception of variation and preferences in ackee (Blighiasapida K.D. Koenig) fruit traits in Benin: implications for domestication and conservation. J EthnobiologyEthnomedicine2010; 6:12.https://doi.org/10 .1186/1746-4269-6-12.

10. Trease GE, Evans WC. Pharmacognosy. 15th Ed. London: Saunders Publishers, 2002, 42-44.

11. Sofowora A. Medicinal Plants and Traditional Medicinal in Africa. 2nd Ed. Sunshine House, Ibadan, Nigeria: Spectrum Books Ltd. Screening Plants for Bioactive Agents, 1993, 134-156.

12. Trease GE, Evans WC. Pharmacognosy: a physician's 
guide to herbal medicine, 13th ed. BailliereTindall, London, 1989, 176-180.

13. AOAC. Official method of analysis 15th Edition. Association of Official Analytical Chemist. Washington, DC. USA, 1990.

14. Ologundudu FA, Obimakinde ET, Osunyemi OS, Akinnifesi OJ. Antimicrobial activity and phytochemical screening of leaf and bark ofBlighiasapida. J Genet Cell Biol, 2019; 2(1):36-43.

15. Saidu1 AN, Mann A, Onuegbu CD. Phytochemical screening and hypoglycemic effect of aqueous Blighia sapida root bark extract on normoglycemic albino rats. Brit J. Pharmaceut Res. 2012; 2(2):89-97.

16. Del-Rio A, Obdulio BG, Castillo J, Marin RR, Ortuno A. Uses and properties of citrus flavonoids. J. Agric. Food Chem. 1977; 45:4505-4515.

17. Okwu DE. Pytochemical and vitamin content of indigenous spices of South Eastern Nigeria. J. Sustain. Agric. Environ. 2004; 6:30-34.

18. Böhm M. Digoxin in patients with heart failure. The New Eng J Med. 1997; 337:129-130.

19. Okwu DE, Okwu ME. Chemical composition of Spondiasmombin Linn plant parts. J Sustain. Agric. Environ. 2004; 6:140-147.

20. Ene AC, Ameh DA, Kwanashie HO, Agomuo PU, Atawodi SE. Preliminary in vivo antimalarial screening of petroleum ether, chloroform and methanol extracts of fifteen plants grown in Nigeria. J Pharmacol Toxicol. 2008; 32:254-260.

21. Onifade OF, Maganda Vera. In vivo activity of ethanolic extract of Alstonia boonei leaves against Plasmodium berghei in mice. J Worldwide Holistic Sustainable Dev. 2015; 1(4):60-68

22. Ajose D, Onifade O, Wemambu II. Phytochemical analysis and in vitro antibacterial evaluation of leaf and bark extracts of Alstoniaboonei. Afr $\mathrm{J}$ Pharmacy Pharmacol, 2019; 13:287291.http://dx.doi.org/10.5897/AJPP2019.5026.

23. Okwu DE, Global J. Pure Appl. Sci. 2001; 8:455-459.

24. Saxena HO, Soni A, Mohammad N, Choubey SK. Phytochemical screening and elemental analysis in different plant parts of Desv. A dashmul species. J. Chem Pharmaceut Res. 2014; 6(5):756-760

25. Hubert $S$. The role of sterols in plant growth and development. Prog Lipid Res. 2003; 42:163-75.

26. Brodsky IG, Balagopal P, Nair KS. Effects of testosterone replacement on muscle mass and muscle protein synthesis in hypogonadal men--a clinical research center study. The J clinical endocrinology and metabolism. 1996; 81(10):3469-75.

27. Theodorakidou M, Nikola OA, Lambrou G. The multiple roles of steroids and anabolic steroids and its relations to cardiovasular and musculoskeletal pathology: a brief review. J Res. Practice Musculoskeletal Sys. 2018; 02:22-30. http://dx.doi.org/10.22540/JRPMS-02-022.

28. Grabmann J. Terpenoids as plant antioxidants. Vitamins \& Hormones. 2005; 72:505-535

29. Munteanu C, Iliuta A. The role of sodium in the body. Balneo Res. J. 2011; 2:70-74. http://dx.doi.org/10.12680/balneo.2011.1015.

30. Dser BL. Hawk's Physiological Chemistry, Edn. 4. New Delhi: Tate McGraw-Hill Publ. Co, 1979, 27-133.

31. Palacios C. The role of nutrients in bone health, from A to Z, Critic Rev Food SciNutr. 2006; 46(8):621-628.

32. Fraga CG. Relevance, essentiality and toxicity of trace elements in human healthMolecul Aspects Med. 2005; 26(4):235-244.

33. Nielsen FH, Hunt JR. Trace elements emerging as important in human nutrition. In: Stumbo PJ. (Ed.), Proceedings of the Fourteenth National Databank Conference, Iowa City: University of Iowa. 1989; p135143.

34. Medical News Today. Health benefits and risks of copper. Accessed from https://www.medicalnewstoday.com/articles/288165\#req uirements on July 21, 2020, 2017.

35. Jeremias CT, David LB, Royden J. Severe ataxia, myelopathy, and peripheral neuropathy due to acquired copper deficiency in a patient with history of gastrectomy JPEN, J. Parenteral Enteral Nutr. 2006; 30:446-450.

36. Osredkar J, Sustar N. Copper and zinc, biological role and significance of copper/zinc imbalance. J Clin. Toxicol. 2011; S3:1-18.

37. Anderson RA. Nutritional factors influencing the glucose/insulin system: Chromium.J.Ame College Nutr. 1997; 16:404-410.

38. Kimura K. Role of essential trace elements in the disturbance of carbohydrate metabolism, Nippon Rinsho. 1996; 54: 79-84.

39. Medline Plus. Phosphorous in diet. Medical Encyclopedia; U.S. National Library of Medicine, 2020. Accessed from https://medlineplus.gov/ency/article/002424.htm on July 21, 2020. 